\author{
INVENTORY OF MEDICINAL PLANTS AND THEIR TRADITIONAL USE BY THE \\ COMMUNITY IN AMESIU VILLAGE, KONAWE REGENCY, SOUTHEAST SULAWESI
}

\title{
INVENTARISASI TUMBUHAN OBAT DAN PEMANFAATANNYA SECARA TRADISIONAL OLEH MASYARAKAT DI DESA AMESIU KABUPATEN KONAWE, SULAWESI TENGGARA
}

\author{
Alkawi $^{1{ }^{* *}}$, Sendy Beatrix Rondonuwu ${ }^{1)}$, Febby Ester Fany Kandou ${ }^{1)}$ \\ ${ }^{1)}$ Program Studi Biologi FMIPA UNSRAT Manado, 95115 \\ *alkawiawi55@gmail.com
}

\begin{abstract}
Amesiu village is one of the areas that has a considerable potency of medicinal plants. This study aims to inventory the types of plants used as medicine and to study the utilization of medicinal plants in the village of Pondidaha Pondidaha District Konawe. This study uses qualitative deskrpative method with data collection techniques through interviews, observations, and documentation. The data of the research results are analyzed descriptively and presented in the form of descriptions, tables and images. The results showed that in Amesiu Village there are 39 species of 27 plant families used by the community as traditional medicine materials. Organs or parts of plants that are utilized as the manufacture of medicinal herbs, namely roots, rhizomes, tubers, stems, bark, leaves, fruits and seeds. The most widely used part of plants as medicine is leaves. The processing process is done by boiling, shredded, pounded and burned. The most widely used way of processing is boiled. Types of diseases that can be treated with medicinal plants as many as 31 types of diseases.
\end{abstract}

Keywords : Inventory, Medicinal Plants, Amesiu Village

\begin{abstract}
ABSTRAK
Desa Amesiu merupakan salah satu wilayah yang memiliki potensi tumbuhan obat yang cukup banyak. Penelitian ini bertujuan untuk menginventarisasi jenis-jenis tumbuhan yang dimanfaatkan sebagai obat dan untuk mengkaji pemanfaatan tumbuhan obat di Desa Amesiu Kecamatan Pondidaha Kabupaten Konawe. Penelitian ini menggunakan metode deskrptif kualitatif dengan teknik pengumpulan data melalui wawancara, observasi, dan dokumentasi. Data hasil penelitian dianalisis secara deskriptif dan disajikan dalam bentuk deskripsi, tabel dan gambar. Hasil penelitian menunjukkan bahwa di Desa Amesiu terdapat 39 spesies dari 27 famili tumbuhan yang dimanfaatkan oleh masyarakat sebagai bahan pengobatan tradisional. Organ atau bagian tumbuhan yang dimanfaaatkan sebagai pembuatan ramuan obat yaitu akar, rimpang, umbi, batang, kulit batang, daun, buah dan biji. Bagian tumbuhan yang paling banyak digunakan sebagai obat yaitu daun. Proses pengolahan dilakukan dengan cara direbus, diparut, ditumbuk dan dibakar. Cara pengolahan yang paling banyak digunakan adalah direbus. Jenis penyakit yang dapat diobati dengan tumbuhan obat sebanyak 31 jenis penyakit.
\end{abstract}

Kata kunci : Inventarisasi, Tumbuhan Obat, Desa Amesiu 


\section{PENDAHULUAN}

Indonesia merupakan negara yang memiliki banyak pulau terbesar yang terletak di kawasan khatulistiwa dan termasuk negara beriklim tropika yang memiliki banyak flora dan fauna. Kekayaan flora dan fauna menjadi salah satu kekayaan alam Indonesia. Di antara kekayaan flora tersebut, banyak di antaranya yang masuk ke dalam kategori tumbuhan obat. Pemanfaatan tumbuhan untuk mengobati suatu penyakit telah banyak dikenal dan bukan menjadi sesuatu yang baru lagi. Ramuan-ramuan tradisional seperti jamu merupakan bukti nyatanya. Sudah tidak terhitung berapa banyak ramuan tradisional yang ada di Indonesia, baik jamu yang sudah mempunyai merk dagang, maupun jamu yang dibuat sendiri (Kusdianti, 2012).

Penggunaan tumbuh-tumbuhan dalam penyembuhan penyakit merupakan bentuk pengobatan tertua di dunia. Setiap daerah memiliki sistem pengobatan tradisional yang khas dan di setiap daerah dijumpai berbagai macam jenis tumbuhan yang dapat dimanfaatkan sebagai obat. Pengobatan tradisional adalah pengobatan yang mengacu pada pengalaman yang diwariskan oleh para leluhur atau nenek moyang secara turun temurun, sehingga menjadi suatu kebiasaan yang sampai sekarang tetap dipertahankan dalam kehidupan masyarakat, terutama yang jauh dari perkotaan atau masyarakat yang hidup di daerah yang sarana pelayanan kesehatannya masih sangat terbatas (Sopandi, 2009).

Desa Amesiu termasuk salah satu Desa yang berada di Kecamatan Pondidaha Kabupaten Konawe Sulawesi Tenggara. Desa Amesiu merupakan salah satu wilayah yang memiliki potensi tumbuhan obat yang cukup banyak. Penggunaan dan pemanfaatan tumbuhan sebagai obat tradisional oleh masyarakat Desa Amesiu telah lama dikenal dan pengetahuan ini telah diwariskan secara turun-temurun. Sampai saat ini masyarakat masih mempertahankan penggunaan tumbuhan sebagai obat tradisional karena selain mudah didapatkan juga tidak perlu mengeluarkan biaya yang besar dibandingkan dengan menggunakan obat modern. Disamping itu, masyarakat meyakini penggunaan tumbuhan obat tidak memiliki efek samping dibandingkan dengan obat modern. Permasalahannya yaitu bahwa sampai saat ini belum ada identifikasi yang jelas tentang nama-nama jenis tumbuhan tersebut secara ilmiah. Berdasarkan hal tersebut maka perlu dilakukan penelitian tentang inventarisasi tumbuhan obat dan pemanfaatannya secara tradisional oleh masyarakat di Desa Amesiu Kecamatan Pondidaha Kabupaten Konawe.

Tujuan dari penelitian ini adalah:

1. Menginventarisasi dan mendeskripsikan jenisjenis tumbuhan obat yang digunakan oleh masyarakat di Desa Amesiu Kecamatan Pondidaha Kabupaten Konawe Provinsi Sulawesi Tenggara

2. Mengkaji pemanfaatan tumbuhan obat di Desa Amesiu Kecamatan Pondidaha Kabupaten Konawe Provinsi Sulawesi Tenggara

\section{METODOLOGI PENELITIAN Waktu dan Tempat}

Penelitian ini telah dilaksanakan selama 2 bulan yaitu mulai bulan Desember 2020-Januari 2021. Lokasi penelitian bertempat di Desa Amesiu Kecamatan Pondidaha Kabupaten Konawe.

\begin{abstract}
Alat dan Bahan
Alat yang digunakan dalam penelitian ini berupa kamera digital, alat perekam (recorder), alat tulis dan buku pengamatan. Bahan penelitian yang diguanakan yaitu semua jenis tanaman obat yang dimanfaatkan oleh masyarakat di Desa Amesiu Kecamatan Pondidaha Kabupaten Konawe.
\end{abstract}

\section{Variabel Penelitian}

Variabel yang diamati dalam penelitian ini yaitu identifikasi jenis, ciri morfologi, manfaat obat (khasiat) dan cara pemanfaatan tumbuhan obat oleh masyarakat di Desa Amesiu Kecamatan Pondidaha Kabupaten Konawe Provinsi Sulawesi Tenggara.

\section{Teknik Pengumpulan Data}

Jenis penelitian yang digunakan dalam penelitian ini yaitu metode deskriptif dengan pendekatan kualitatif. Teknik pengambilan sampel dilakukan dengan menggunakan metode snowball sampling, yaitu suatu pendekatan yang dilakukan untuk menemukan informan kunci yang memiliki banyak informasi. Teknik ini dilakukan dengan menggunakan bantuan dari tokoh masyarakat, tetua adat, bidan desa dan masyarakat untuk menemukan informasi kunci yaitu pengobat tradisional (batra/dukun).

Metode pengumpulan data dilakukan untuk mengumpulkan data-data atau informasi dalam suatu penelitian. Untuk mendapatkan data yang diperlukan, digunakan beberapa metode pengumpulan data sebagai berikut:

\section{Wawancara}


Metode yang digunakan dalam pengumpulan data dilakukan dengan wawancara secara semi terstruktur yaitu dengan melakukan wawancara kepada responden dengan beberapa pertanyaan yang sudah terstruktur, selanjutnya pertanyaan tersebut satu persatu diperdalam untuk mencari informasi atau keterangan lebih lanjut. Wawancara semi terstruktur digunakan guna mendapatkan data jenis-jenis tumbuhan obat tradisional dengan tokoh masyarakat, tetua adat, dukun (batra), bidan desa dan beberapa masyarakat desa yang berpedoman pada daftar pertanyaan antara lain: nama lokal tanaman, bagian yang dimanfaatkan, manfaatnya dan cara pemanfaatannya.

\section{Observasi}

Observasi dilakukan dengan mengadakan pengamatan dari dekat untuk mengumpulkan data malalui pengamatan secara langsung terhadap peristiwa yang terjadi di lokasi penelitian. Pengambilan gambar spesies tumbuhan yang dimanfaatkan sebagai obat dipandu oleh masyarakat yang telah diwawancarai sebelumnya. Pengambilan gambar spesies tumbuhan obat digunakan untuk mengidentifikasi tanaman obat tersebut.

\section{Dokumentasi}

Pendokumentasian yang dilakukan berupa tulisan menggunakan alat tulis, rekaman menggunakan recorder, dan gambar menggunakan kamera pada saat pengambilan data berlangsung seperti saat dilakukan wawancara dan pengambilan gambar spesies tumbuhan yang digunakan sebagai obat oleh masyarakat Desa Amesiu berdasarkan wawancara yang dilakukan.

\begin{abstract}
Analisis Data
Data yang diperoleh di lapangan disajikan dalam bentuk tabulasi dan dianalisis menggunakan metode deskripftif kualitatif yaitu dengan mendeskripsikan sifat dan karateristik, morfologi akar, batang, daun, bunga, buah, biji, serta manfaatnya dan cara pemanfaatan tumbuhan obat tersebut. Identifikasi tumbuhan yang digunakan sebagai obat tradisional dilakukan dengan menggunakan pedoman pustaka Atlas Tumbuhan Obat Jilid 1, 2, 3, 4, 5, dan 6, browsing internet (plantamor) dan pustaka lainnya.
\end{abstract}

\section{HASIL DAN PEMBAHASAN}

\section{Jenis-Jenis Tumbuhan Obat yang dimanfaatkan oleh Masyarakat Desa Amesiu}

Berdasarkan hasil wawancara dengan 15 responden pada masyarakat di Desa Amesiu yang terdiri dari 3 batra dan 12 masyarakat yang mengetahui tentang penggunaan tumbuhan obat diketahui terdapat 39 spesies tumbuhan yang dimanfaatkan sebagai obat tradisional yang dikelompokan menjadi 27 famili. Tumbuhan obat yang banyak digunakan oleh masyarakat Desa Amesiu yaitu spesies tumbuhan dari famili Zingiberaceae, Lamiaceae dan Asteraceae yaitu sebanyak 3 spesies tumbuhan. Jenis-jenis tumbuhan obat yang dimanfaatkan oleh masyarakat Desa Amesiu dapat dilihat pada Tabel 1.

Tabel 1. Spesies tumbuhan obat yang dimanfaatkan oleh masyarakat Desa Amesiu

\begin{tabular}{|c|c|c|c|c|}
\hline \multirow{2}{*}{ No } & \multicolumn{3}{|c|}{ Nama Tumbuhan } & \multirow{2}{*}{ Familia } \\
\hline & Lokal & Umum & Ilmiah & \\
\hline 1 & O'liku & Lengkuas & Alpinia galanga L. Swartz. & Zingiberaceae \\
\hline 2 & Lo'io & Jahe merah & Zingiber officinale var. rubrum & Zingiberaceae \\
\hline 3 & O'kuni & Kunyit & Curcuma domestica Val. & Zingiberaceae \\
\hline 4 & Kumis kucing & Kumis kucing & Orthosiphon aristatus (Blume) Miq. & Lamiaceae \\
\hline 5 & Cemangi & Kemangi & Ocimum sanctum $\mathrm{L}$. & Lamiaceae \\
\hline 6 & Mayana & Miyana & $\begin{array}{l}\text { Plectranthus scutellarioides (L.) R.Br } \\
\text { Chromolaena odorata (L.) R.M.King }\end{array}$ & Lamiaceae \\
\hline 7 & Paso-paso & Kirinyuh & \& H.Rob & Asteraceae \\
\hline 8 & Bunga kertas & Kembang kertas & Melampodium divaricatum & Asteraceae \\
\hline 9 & Kurawolio & Bandotan & Ageratum conyzoides $\mathrm{L}$. & Asteraceae \\
\hline 10 & $\begin{array}{l}\text { Lasuna wila } \\
\text { Lasuna }\end{array}$ & Bawang putih & Allium sativum $\mathrm{L}$. & Liliaceae \\
\hline 11 & momea & Bawang merah & Allium ascalonicum $L$. & Liliaceae \\
\hline
\end{tabular}




\begin{tabular}{|c|c|c|c|c|}
\hline 12 & $\begin{array}{l}\text { Purundawa } \\
\text { Bunga }\end{array}$ & Bayam duri & Amaranthus spinosus L. & Amaranthaceae \\
\hline 13 & kancing & Bunga kenop & Gomphrena globusa L. & Amaranthaceae \\
\hline 14 & Kawu-kawu & Kapuk randu & Ceiba pentandra (L.) Gaertn & Malvaceae \\
\hline 15 & Sidaguri & Sidaguri & Sida rhombifolia $\mathrm{L}$. & Malvaceae \\
\hline 16 & Paria ndirisa & Gambas & Luffa acutangula (L.) Roxb. & Cucurbitaceae \\
\hline 17 & Konduru & Bligo & Benincasa hispida (Thunb.) Cogn. & Cucurbitaceae \\
\hline 18 & Patikan kebo & Patikan kebo & Euphorbia hirta L. & Euphorbiaceae \\
\hline 19 & Tawa opu-opu & Keroton & Croton hirtus L'Her. & Euphorbiaceae \\
\hline 20 & Gola-gola & Rambusa & Passiflora foetida $\mathrm{L}$. & Passifloraceae \\
\hline 21 & Bunga jam 8 & Bunga pukul 8 & Turnera subulata & Passifloraceae \\
\hline 22 & Dambu watu & Jambu biji & Psidium guajava & Myrtaceae \\
\hline 23 & sereh & Serai & Cymbopogon citratus (DC.) Stapf & Poaceae \\
\hline 24 & Paci & Pacar air & Impatiens balsamina $\mathrm{L}$ & Balsaminaceae \\
\hline 25 & Obite & Sirih & Piper betle L. & Piperaceae \\
\hline 26 & Putri malu & Putri malu & Mimosa pudica $\mathrm{L}$. & Leguminosae \\
\hline 27 & Pisang kepo & Pisang kepok & Musa paradisiaca var. Balbisina Colla & Musaceae \\
\hline 28 & Kaluku & Kelapa gading & Cocos nucifera var. Eburnea & Arecaceae \\
\hline 29 & Kapaya & Pepaya & Carica papaya & Caricaceae \\
\hline 30 & Sukun & Sukun & Artocarpus altilis & Moraceae \\
\hline 31 & Tapak dara & Tapak dara & Catharanthus roseus (L.) G.Don & Apocynaceae \\
\hline 32 & Tameau & Ciplukan & Physalis angulata L. & Solanaceae \\
\hline 33 & Meniran & Meniran & Phyllanthus niruri & Phyllanthaceae \\
\hline 34 & Mengkudu & Mengkudu & Morinda citrifolia $\mathrm{L}$. & Rubiaceae \\
\hline 35 & Srikaya & $\begin{array}{l}\text { Sirsak } \\
\text { Belimbing }\end{array}$ & Annona muricata $\mathrm{L}$. & Annonaceae \\
\hline 36 & Takule & wuluh & Averrhoa bilimbi L. & Oxalidaceae \\
\hline 37 & Walisongo & Wali songo & Schefflera arboricola (Hayata) Merr & Araliaceae \\
\hline 38 & Taipa & Mangga & Mangifera indica $\mathrm{L}$. & Anacardiaceae \\
\hline 39 & Panda bau & Pandan wangi & Pandanus amaryllifolius Roxb. & Pandanaceae \\
\hline
\end{tabular}

\section{Pemanfaatan Tumbuhan Obat Berdasarkan Bagian Tumbuhan yang digunakan}

Bagian tumbuhan yang dimanfaatkan oleh masyarakat Desa Amesiu terdiri dari akar, batang, kulit batang, daun, buah, bunga, biji, umbi, rimpang dan semua bagian tumbuhan. Bagian tumbuhan yang paling banyak digunakan terdapat pada bagian daun yaitu sebanyak 16 spesies tumbuhan. Hal ini disebabkan karena daun lebih mudah diperoleh dan diramu sebagai obat dibandingkan dengan bagian tumbuhan yang lain seperti kulit batang dan akar tanaman. Handayani (2003) menyatakan, bagian organ tumbuhan yang paling banyak digunakan sebagai obat tradisional adalah daun. Hal ini di karenakan daun pada umumnya memiliki tekstur yang lunak sebab mempunyai kandungan air yang tinggi, selain itu daun merupakan tempat akumulasi fotosintesis yang mengandung unsur-unsur zat organik dalam menyembuhkan berbagai penyakit.

Menurut Cunningham (1991 dalam Swanson, 1998) bagian tumbuhan yang perlu dibatasi penggunaannya dalam pengobatan yaitu bagian akar, batang, kulit kayu dan umbi karena dapat langsung mematikan tumbuhan tersebut. Menurut Siswanto (2002) pemanfaatan tumbuhan berkhasiat obat tradisional yang mencakup berbagai organ tumbuhan yang dijadikan sebagai obat dapat diambil seluruh atau sebagian organnya untuk diramu sebagai tumbuhan berkhasiat obat tradisional. Bagian tumbuhan yang digunakan sebagai obat dapat dilihat pada Tabel 2.

\section{Cara Pemanfaatan Tumbuhan Obat}

Pada umumnya masyarakat di Desa Amesiu lebih banyak mengolah ramuan tumbuhan 
yang berkhasiat obat dengan cara direbus kemudian air rebusan diminum. Terdapat 22 spesies tumbuhan yang digunakan dengan cara direbus, 14 spesies dengan cara ditumbuk, 6 spesies dengan cara diparut dan 2 spesies dengan cara di bakar. Adapun beberapa alasan yang disampaikan oleh pengobat tradisional (batra) mengapa tumbuhan obat direbus, salah satunya yaitu pada saat proses perebusan, khasiat yang ada pada organ tumbuhan akan menyebar dan menyatu dengan air rebusan yang disebabkan karena adanya pemanasan. Hardadi (2005), berpendapat bahwa merebus merupakan cara yang efektif, ekonomis dan efisien karena dengan merebus berulang kali tidak akan mempengaruhi khasiat obat.

Menurut Mahendra (2006), tujuan merebus tumbuhan obat adalah untuk memindahkan zat-zat berkhasiat yang ada pada tumbuhan ke dalam air, kemudian diminum untuk kebutuhan pengobatan. Pengolahan tumbuhan obat dengan cara direbus dapat mengurangi rasa pahit dibandingkan jika dimakan langsung dan juga lebih steril karena bisa membunuh kuman ataupun bakteri patogen pada saat proses pemanasan dengan cara direbus (Novianti, 2014). Cara pemanfaatan tumbuhan obat dapat dilihat pada Tabel 2.

\section{Sumber Perolehan Jenis Tumbuhan yang dimanfaatkan Sebagai Obat Tradisional}

Berdasarkan hasil wawancara dapat diketahui bahwa masyarakat Desa Amesiu lebih banyak memanfaatkan tumbuhan obat yang dibudidayakan yaitu sebanyak 26 spesies tumbuhan. Tumbuhan tersebut dibudidayakan dengan cara memanfaatkan pekarangan rumah dan ada pula yang difungsikan sebagai tanaman hias. Selain itu, sebanyak 10 spesies merupakan tumbuhan liar yang dapat ditemukan di hutan, kebun, dan pinggir jalan. Selain dari hasil budidaya dan habitat liar masyarakat Desa Amesiu juga memperoleh tumbuhan untuk pengobatan penyakit dengan membeli dipasar. Dapat dilihat pada Tabel 2. Alasan masyarakat Desa Amesiu membeli tumbuhan dipasar yaitu lebih mudah dan praktis.

\section{Manfaat Tumbuhan Obat Menurut Masyarakat Desa Amesiu}

Dari 39 spesies tumbuhan obat, ada 31 jenis penyakit yang dapat disembuhkan dengan menggunakan tumbuhan obat tradisional yaitu penyakit kulit, sakit tenggorokan, masuk angin, cacar air, batuk, influenza, jantung, muntah darah, demam, leukemia, hipertensi, menyembuhkan luka, maag, asam urat, malaria, tipes, asma, kanker usus, diabetes, rematik, sakit perut, patah tulang, kanker kandungan, iritasi pada mata, penawar racun, penyakit kuning, menghilangkan bekas gigitan nyamuk, batu ginjal, kolesterol, mual dan sakit gigi. Keseluruhan jenis-jenis penyakit tersebut digolongkan ke dalam empat macam yaitu penyakit kronik, penyakit menular, penyakit tidak menular dan untuk perawatan kesehatan.

Penyakit kronik adalah penyakit yang berlangsung lama dan sering menyebabkan kematian (Dahlan, 2011). Jenis penyakit yang tergolong dalam penyakit kronik yang dapat diobati dengan tumbuhan obat di Desa Amesiu diantaranya jantung, kanker usus, kanker kandungan, hipertensi, diabetes, batu ginjal, kolesterol, maag, leukemia, penyakit kuning, asma, muntah darah, asam urat, tipes dan rematik. Tumbuhan yang dapat digunakan untuk mengobati penyakit tersebut antara lain kemangi (Ocimum sanctum L.), kelapa gading (Cocos nucifera var. Eburnea), keroton (Croton hirtus L'Her), pacar air (Impatiens balsamina L.), meniran (Phyllanthus niruri), bawang putih (Allium sativum L.), bunga kenop (Gomphrena globusa L.), mengkudu (Morinda citrifolia L.), belimbing wuluh (Averrhoa bilimbi L.), rambusa (Passiflora foetida L.), ciplukan (Physalis angulata L.), pandan wangi (Pandanus amaryllifolius Roxb), mengkudu (Morinda citrifolia L.), bandotan (Ageratum conyzoides L.), kapuk randu (Ceiba pentandra (L.) Gaertn), pisang kepok (Musa paradisiaca var. Balbisina Colla), bayam duri (Amaranthus spinosus L.), sukun (Artocarpus altilis), patikan kebo (Euphorbia hirta L.), miana (Plectranthus scutellarioides (L.) R.Br), sidaguri (Sida rhombifolia L.), bligo (Benincasa hispida (Thunb.) Cogn.), bunga pukul 8 (Turnera subulata) dan sirsak (Annona muricata L.).

Penyakit menular merupakan penyakit yang disebabkan oleh kuman yang menjangkit pada tubuh manusia. Kuman dapat berupa virus, bakteri, amoeba dan jamur (Dahlan, 2011). Jenis penyakit yang tergolong dalam penyakit menular yang dapat diobati menggunakan tumbuhan obat di Desa Amesiu diantaranya influenza, cacar air, malaria dan penyakit kulit (panu, alergi). Tumbuhan yang digunakan untuk mengobati jenis penyakit menular yaitu kumis kucing (Orthosiphon aristatus (Blume) Miq), kunyit (Curcuma domestica Val.), sidaguri (Sida rhombifolia L.), papaya (Carica papaya), 
lengkuas (Alpinia galanga L. Swartz), bunga kenop (Gomphrena globusa L.) dan putri malu (Mimosa pudica L.).

Penyakit tidak menular didefinisikan sebagai penyakit yang tidak disebabkan oleh kuman tetapi disebabkan oleh masalah fisiologis atau metabolisme pada jaringan tubuh manusia (Dahlan, 2011). Jenis penyakit yang dapat diobati menggunakan tumbuhan obat yaitu masuk angin, demam, sakit perut, mual, sakit gigi, batuk dan sakit tenggorokan. Tumbuhan yang dapat digunakan untuk mengobati penyakit tersebut antara lain jahe merah (Zingiber officinale var. rubrum), bawang merah (Allium ascalonicum L.), gambas (Luffa acutangula (L.) Roxb.), jambu biji (Psidium guajava), walisongo (Schefflera arboricola (Hayata) Merr), manga (Mangifera indica L.) dan kumis kucing (Orthosiphon aristatus (Blume) Miq.),

Adapun beberapa spesies tumbuhan yang digunakan untuk menjaga kesehatan, seperti untuk menghilangkan bekas gigitan nyamuk, luka, penawar racun, iritasi pada mata dan patah tulang yaitu tapak dara (Catharanthus roseus (L.) G.Don), kirinyuh (Chromolaena odorata (L.) R.M.King dan H.Rob), kembang kertas (Melampodium divaricatum), kelapa gading (Cocos nucifera var. Eburnea), sirih (Piper betle L.) dan serai (Cymbopogon citratus (DC.) Stapf).
Dari 39 spesies tumbuhan obat tersebut ada tumbuhan yang tidak hanya dimanfaatkan untuk 1 atau 2 jenis penyakit saja tetapi digunakan untuk pengobatan beberapa macam penyakit, seperti jahe merah (Zingiber officinale var. rubrum) dapat digunakan untuk sakit tenggorokan dan masuk angin, kumis kucing (Orthosiphon aristatus (Blume) Miq) digunakan untuk batuk, influenza dan sakit tenggorokan, bunga kenop (Gomphrena globusa L.) untuk penyakit hipertensi dan gangguan kulit, kelapa gading (Cocos nucifera var. Eburnea) digunakan untuk penyakit jantung dan sebagai penawar racun, mengkudu (Morinda citrifolia L.) untuk kolesterol dan hipertensi, sidaguri (Sida rhombifolia L.) untuk asam urat dan malaria, meniran (Phyllanthus niruri) digunakan untuk mengobati asam urat, hipertensi dan batu ginjal.

Selain itu, terdapat penyakit yang tidak hanya dapat disembuhkan dengan 1 jenis tumbuhan seperti untuk penyakit hipertensi dapat disembuhkan dengan menggunakan bawang putih (Allium sativum L.), meniran (Phyllanthus niruri), mengkudu (Morinda citrifolia L.), kirinyuh (Chromolaena odorata (L.) R.M.King dan H.Rob) dan belimbing wuluh (Averrhoa bilimbi L.). Manfaat tumbuhan obat dalam menyembuhkan penyakit dapat dilihat pada Tabel 2.

Tabel 2. Bagian yang digunakan, cara pemanfaatan, sumber perolehan dan manfaat tumbuhan obat

\begin{tabular}{|c|c|c|c|c|c|}
\hline no & Nama umum & $\begin{array}{c}\text { Bagian yang } \\
\text { digunakan }\end{array}$ & $\begin{array}{c}\text { Cara } \\
\text { pemanfaatannya }\end{array}$ & Sumber perolehan & $\begin{array}{l}\text { Manfaat menurut } \\
\text { masyarakat }\end{array}$ \\
\hline 1 & Lengkuas & Rimpang & Diparut & Tanaman pekarangan & Penyakit kulit (panu) \\
\hline 2 & Jahe merah & Rimpang & Direbus & Tanaman pekarangan & $\begin{array}{l}\text { Sakit tenggorokan } \\
\text { dan masuk angin }\end{array}$ \\
\hline 3 & Kunyit & Rimpang & Ditumbuk & Tanaman pekarangan & Cacar air \\
\hline 4 & Kumis kucing & Semua bagian & Direbus & Tanaman pekarangan & $\begin{array}{l}\text { Batuk, influenza dan } \\
\text { sakit tenggorokan }\end{array}$ \\
\hline 5 & Kemangi & Biji & Ditumbuk & Tanaman pekarangan & Jantung \\
\hline 6 & Miyana & Daun & Direbus/ditumbuk & Tanaman pekarangan & Muntah darah \\
\hline 7 & $\begin{array}{l}\text { Kirinyuh } \\
\text { Kembang }\end{array}$ & Daun & Ditumbuk & Liar & Menyembuhan luka \\
\hline 8 & kertas & Daun & Ditumbuk & Tanaman pekarangan & Luka \\
\hline 9 & Bandotan & Semua bagian & Ditumbuk & Liar & Maag kronis \\
\hline 10 & Bawang putih & Umbi & Diparut/dibakar & Pasar & Hipertensi \\
\hline 11 & Bawang merah & Umbi & Diparut & Pasar & Demam \\
\hline 12 & Bayam duri & Daun & Ditumbuk & Liar & $\begin{array}{l}\text { Leukimia } \\
\text { Gangguan kulit dan }\end{array}$ \\
\hline 13 & Bunga kenop & Semua bagian & Direbus & Tanaman pekarangan & hipertensi \\
\hline 14 & Kapuk randu & Daun & Ditumbuk & Tanaman pekarangan & Obat maag \\
\hline 15 & Sidaguri & Semua bagian & Direbus & Liar & Asam urat dan \\
\hline
\end{tabular}




\begin{tabular}{|c|c|c|c|c|c|}
\hline & & & & & malaria \\
\hline 16 & Gambas & Biji & Ditumbuk & Pasar & Demam \\
\hline 17 & Bligo & Buah & Diparut & Tanaman pekarangan & Tipes \\
\hline 18 & Patikan kebo & Daun & Direbus & Liar & Asma \\
\hline 19 & Keroton & Daun & Direbus & Liar & Kanker usus \\
\hline 20 & Rambusa & Semua bagian & Direbus & Liar & Diabetes \\
\hline 21 & Bunga pukul 8 & Akar & Direbus & Tanaman pekarangan & Rematik \\
\hline 22 & Jambu biji & Daun & Direbus & Tanaman pekarangan & Sakit perut \\
\hline 23 & Serai & Batang & Ditumbuk & Tanaman pekarangan & Patah tulang \\
\hline 24 & Pacar air & Daun & Diparut/direbus & Tanaman pekarangan & Kanker kandungan \\
\hline 25 & Sirih & Daun & Ditumbuk & Tanaman pekarangan & Iritasi pada mata \\
\hline 26 & Putri malu & Semua bagian & Direbus & Liar & (alergi) \\
\hline 27 & Pisang kepok & Buah & Direbus & Tanaman pekarangan & Obat maag \\
\hline 28 & Kelapa gading & Buah & Direbus/dibakar & Tanaman pekarangan & $\begin{array}{l}\text { Penyakit jantung, } \\
\text { penawar racun }\end{array}$ \\
\hline 29 & Pepaya & Daun & Direbus & Tanaman pekarangan & Malaria \\
\hline 30 & Sukun & Daun & Direbus & Tanaman pekarangan & $\begin{array}{l}\text { Penyakit kuning } \\
\text { Menghilangkan } \\
\text { bekas gigitan }\end{array}$ \\
\hline 31 & Tapak dara & Bunga & Ditumbuk & Tanaman pekarangan & nyamuk \\
\hline 32 & Ciplukan & Semua bagian & Direbus & Liar & $\begin{array}{l}\text { Diabetes } \\
\text { Asam urat, }\end{array}$ \\
\hline 33 & Meniran & Daun & Direbus/ditumbuk & Liar & $\begin{array}{l}\text { ginjal } \\
\text { Kolesterol dan }\end{array}$ \\
\hline 34 & Mengkudu & Buah & Diparut & Tanaman pekarangan & hipertensi \\
\hline 35 & Sirsak & Daun & Ditumbuk & Tanaman pekarangan & Rematik \\
\hline 36 & $\begin{array}{l}\text { Belimbing } \\
\text { wuluh }\end{array}$ & Daun & Direbus & Tanaman pekarangan & Hipertensi \\
\hline 37 & Wali songo & Kulit batang & Direbus & Tanaman pekarangan & Mual \\
\hline 38 & Mangga & Kulit batang & Direbus & Tanaman pekarangan & Sakit gigi \\
\hline 39 & Pandan wangi & Daun & Direbus & Tanaman pekarangan & Diabetes \\
\hline
\end{tabular}

\section{KESIMPULAN}

Berdasarkan penelitian yang telah dilakukan di Desa Amesiu tentang pemanfaatan tumbuhan obat oleh masyarakat Desa Amesiu dapat disimpulkan bahwa terdapat 39 spesies tumbuhan berkhasiat obat yang digunakan oleh masyarakat untuk menyembuhkan penyakit yang digolongkan ke dalam 27 famili. Tumbuhan obat yang paling banyak digunakan yaitu spesies tumbuhan dari famili Zingiberaceae, Lamiaceae dan Asteraceae yaitu sebanyak 3 spesies tumbuhan pada masing-masing famili. Dari hasil penelitian ini dapat diketahui bahwa bagian tumbuhan yang paling banyak digunakan yaitu pada bagian daun sebanyak 16 spesies tumbuhan. Masyarakat di Desa Amesiu lebih banyak mengolah tumbuhan yang berkhasiat obat dengan cara direbus yaitu sebanyak 22 spesies tumbuhan obat.

\section{SARAN}

Penelitian lebih lanjut perlu dilakukan untuk mengetahui kandungan atau senyawa aktif dari setiap tumbuhan yang berperan dalam penyembuhan setiap penyakit.

\section{DAFTAR PUSTAKA}

Dahlan, M. 2011. Statistik untuk Kedokteran dan Kesehatan. Salemba Medika, Jakarta.

Handayani, L. 2003. Mengatasi Penyakit Anak dengan Ramuan Tradisional. Agro Media Pustaka, Jakarta. 
Hardadi. 2005. Musnahkan Penyakit Dengan Tanaman Obat. Puspa Swara, Jakarta.

Mahendra, B. 2006. 13 Jenis Tanaman Obat Ampuh. Penebar Swadaya, Jakarta.

Novianti. 2014. Kajian Etnofarmakognosi dan Etnofarmakologi Penggunaan Tumbuhn
Obat di Desa Cisangkal Kecamatan Cihurip Kabupaten Garut Tahun 2014. Jurnal lmiah Famako Bahari. 5: 1-19.

Sopandi. 2009. Tanaman Obat Tradisional. Jilid 1, 2, Dan 3. Sarana Panca Karya Nusa, Bandung. 